Corrigendum

\title{
Maybe not the king, but an invaluable subordinate: a commentary on Avison and Malaurent's advocacy of 'theory light' IS research
}

\section{Lynne Markus}

Journal of Information Technology (2015) 30, 90. doi:10.1057/jit.2015.4

Correction to: Journal of Information Technology (2014) 29 (4), 341-345. doi:10.1057/jit.2014.19

The following reference 'Davison, R.M., Martinsons, M.G. and Ou, C.X.J. (2012). The Roles of Theory in Canonical Action Research, MIS Quarterly 36(3): 763-786' was used in this article. However, the author 'R.M. Davison' was mistakenly written as 'R.M. Davidson' in both the list of references and in-text citations. 